\title{
Gene flow and selection evidence of sandalwood (Santalum album) under various population structures in Gunung Sewu (Java, Indonesia), and its effects on genetic differentiation
}

\author{
YENI W.N. RATNANINGRUM ${ }^{1, \vartheta}$, SAPTO INDRIOKO ${ }^{2, \bullet \bullet}$, ENY FARIDAH ${ }^{3}$, ATUS SYAHBUDIN ${ }^{4}$ \\ ${ }^{1}$ Laboratory of Forest Seed Science and Technology, Faculty of Forestry, Universitas Gadjah Mada. Bulaksumur, Sleman 55281, Yogyakarta, Indonesia, \\ Tel.: +62-274-550541; Fax.: +62-274-550543, ’email: yeni.wnr@ugm.ac.id; yeniratnaningrum@gmail.ac.id; \\ ${ }^{2}$ Laboratory of Forest Genetics and Tree Improvement, Faculty of Forestry, Universitas Gadjah Mada. Bulaksumur, Sleman 55281, Yogyakarta, \\ Indonesia. Tel./Fax.: +62-274-545639, "v email: sindrioko@ugm..ac.id; \\ ${ }^{3}$ Laboratory of Plant Physiology, Faculty of Forestry, Universitas Gadjah Mada. Bulaksumur, Sleman 55281, Yogyakarta, Indonesia \\ ${ }^{4}$ Laboratory of Dendrology and Ethnobotany, Faculty of Forestry, Universitas Gadjah Mada. Bulaksumur, Sleman 55281, Yogyakarta, Indonesia
}

Manuscript received: 6 June 2017. Revision accepted: 28 September 2017.

\begin{abstract}
Ratnaningrum YWN, Indrioko S, Faridah E, Syahbudin A. 2017. Gene flow and selection evidence of sandalwood (Santalum album) under various population structures in Gunung Sewu (Java, Indonesia), and its effects on genetic differentiation. Biodiversitas 18: 1493-1505. Field observations on population structures and isoenzyme analysis were conducted to determine gene flow and selection evidence of sandalwood under various population structures in Gunung Sewu, and its effects on genetic differentiation. Sandalwood (Santalum album Linn., Santalaceae) is origin to the south-eastern islands but recently emerged as new landraces in Java Island, Indonesia. Results suggested that (i) natural barriers contributed to habitat fragmentation and disrupted gene flow among populations; (ii) gene flow affected selection processes regarding bottleneck effects and genetic drifts, which determined allelic richness and population diversity; and (iii) variation on gene flow and selection processes affected genetic differentiation among populations. Gene flow restriction and genetic drift occurred when population had lower genetic base, highly clonalized, fragmented, and/or more inbreeding in mating. Genetic differentiation was highest between populations within Timor island, and between Gunung Sewu (Java Island) and Sumba-Timor islands. Populations were not clustered based on geographical sites, but more by the similarity of genetic structures. Genetic differentiations were the combined effect of the differences on genetical processes regarding gene flow and selection events. Both differences existed due to differences on (i) population structures including landscape, clonality and parental genetic composition, and (ii) the disturbance histories of population, which affected the equilibrium between gene flow and drift. These findings emphasized the importance of larger gene flow and genetic base to naturally maintain genetical processes of sandalwood population under various landscapes structures.
\end{abstract}

Keywords: Clonality, gene flow, fragmentation, genetic base, genetic differentiation, Santalum album, selection

\section{INTRODUCTION}

Evolutionary processes such as selection and migration, along with ecological factors responsible for gene flow such as pollen and seed dispersal, contribute to the dynamics of genetic structure within and among populations (Craft and Ashley 2007; Pautasso 2009; Schmidt et al. 2009; Garfi et al. 2013). When populations become fragmented or isolated, gene flow may be disrupted, resulting in the alteration of mating pattern, loss of genetic diversity, and increased genetic drift and differentiation (Warburton et al. 2000; Byrne et al. 2003; Bottin et al. 2007; Moreira et al. 2015). Habitat fragmentation could also lead to reproductive isolation (Warburton et al. 2000; Torres et al. 2003), poor recruitment (Byrne et al. 2003), and population fitness reduction through inbreeding or pollen limitation (Lhuillier et al. 2006; Bottin et al. 2007; Agullo et al. 2015). Furthermore, the transformation history of landscapes (Craft and Ashley 2007; Schmidt et al. 2009; Garfi et al. 2013; Moreira et al. 2015) and the human activities (Warburton et al. 2000; Kettle et al. 2007; Agullo et al.
2015), as well as the occurrence of physical barriers i.e. mountains, cliffs or oceans (Byrne et al. 2003; Bottin et al. 2007; Craft and Ashley 2007; Rao et al. 2007; Dani et al. 2011; Cursach et al. 2012; Hmeljevski et al. 2014), may cause habitat isolation which restrict gene flow and lead to the genetic structuring. Recent genetic differentiation may also be caused by drift and gene flow in the past (Lutz et al. 2000). Habitat fragmentation might cause bottlenecks effects due to a low genetic base of the remnant parents, and the events of selection might play an important role (Bottin et al. 2007; Garfi et al. 2013; Moreira et al. 2015).

The Outer Arc of Banda Islands, now is the southeastern parts of Indonesian archipelagos, has been believed as the origin of sandalwood worldwide (Harbaugh and Baldwin 2007; Rao et al. 2007). Santalum album Linn (Santalaceae), herein after referred to sandalwood, produce heartwood containing 1.5 to $5 \%$ of $\beta$-santalol, a strong, specific fragrances of oil. Its heartwood is widely used for wood carving, art, religious and medicinal purposes. Its oil is the materials of cosmetics, perfumes and aroma-therapy, and was considered containing anti-melanoma compounds (Rao et al. 2007; Dani et al. 2011; Anonymous 2012; da 
Silva et al. 2016). However, significant genetic depletion was reported throughout the world, highlighting the forest fragmentation as the main factor responsible for sandalwood extinction (Warburton et al. 2000; Byrne et al. 2003; Suma and Balasundaran 2003; Lhuillier et al. 2006; Bottin et al. 2007; Rao et al. 2007; Dani et al. 2011; Indrioko and Ratnaningrum 2015a, 2015b; da Silva et al. 2016). In 1994, sandalwood was first listed as Vulnerable on the IUCN Red List due to habitat degradation as the results of population size reduction (IUCN 1994). Considering a rapid degradation, the Vulnerable status might be - raised up to Endangered, Critically Endangered or even Extinct in the Wild, and therefore the conservation status supposed to be re-evaluated (IUCN 2009). Since 2004, sandalwood was even considered Extinct in the Wild in most of its native in the south-eastern islands of Indonesia (Anonymous 2012).

In spite of significant degradation in their origin in the South-eastern islands of Indonesia, new landraces of sandalwood extended along geographical gradients in Gunung Sewu Geopark, a $1300 \mathrm{~km}^{2}$ mountainous limestone zones in the central part of Java Island (Ratnaningrum and Indrioko 2014, 2015, 2016; Indrioko and Ratnaningrum 2015a, b). The occurrence of these new landraces sounds promising for any of rehabilitation efforts. However, they are naturally isolated due to the restriction of the up and down formation of various landscape types. Some of them are also fragmented due to any of geographical, evolutionary and disturbance histories. Many studies on sandalwood reported genetic structuring due to various population barriers (Byrne et al. 2003; Bottin et al. 2007; Dani et al. 2011) and/or mating constraints (Warburton et al. 2000; Rao et al. 2007; Tamla et al. 2012). Considering this, this study hypothesized that there are consequences of population barriers to genetic structures.

This study analyzed gene flow and selection evidence of sandalwood under various population structures in Gunung Sewu, Java Island, and its effects on genetic differentiation. The comparison was also made with those of its origin in Timor and Sumba Islands. Field observations which determined the population structure parameters, and biochemical marker gene analysis, were combined to answer the following questions: (i) Does natural barriers contribute to the habitat fragmentation, which restricts gene flow among populations?; (ii) Does the restricted vs. connected gene flow affect selection processes within population?; and (iii) Does the variation on gene flow and selection processes consequentially result in genetic differentiation among populations? Field inventory was conducted to measure population structures. Isozyme analysis was conducted to determine the allelic richness, which implies the existence of bottleneck effects and genetic drifts as the evidence of selection. Based on the allele frequency, the genetic distance was measured and the dendrogram was then constructed to identify genetic differentiation among populations. Based on the betweenpopulation genetic diversity, the migration rate was calculated to estimate gene flow among populations.

\section{MATERIALS AND METHODS}

\section{Study area}

Gunung Sewu is the mountainous limestone zones in Java Island, the central parts of Indonesian archipelagos, which grew through dissolution as the limestone was raised from the seabed about 1.8 million years ago. Recently Gunung Sewu areas stretched $85 \mathrm{~km}$ west-east covers three GeoAreas of Gunungkidul (Yogyakarta), Wonogiri (Central Java), and Pacitan (East Java) with an approximate area of $1300 \mathrm{~km}^{2}$. Based on this geographical formation history, Gunungkidul GeoArea is now derived into three zonations: (1) Northern Zone, consisted of the Batur Agung Highland at $300 \mathrm{~m}$ to $800 \mathrm{~m}$ asl, and the lowland of Sambipitu formation at $200 \mathrm{~m}$ to $300 \mathrm{~m}$ asl; (2) Middle Zone, the lowland basin of Ledok Wonosari at $150 \mathrm{~m}$ to 300m asl; and (3) Southern Zone, the Pegunungan Seribu Karst areas at $0 \mathrm{~m}$ to $200 \mathrm{~m}$ asl. Gunung Sewu possessed two seasons. Rainy season occurs during October to March and the dry season takes place from April to September. As it is adjacent to the Indian Ocean, Gunung Sewu areas has two types of climate -- $A w$, the semi-arid to arid type that is characterized by a long drought; and $A m$ which represents an intermediate condition between the tropical and subtropical climate (Simanjuntak 2002; Haryono and Suratman 2010). In Gunung Sewu, new landraces of sandalwood occurred at various types of landscapes which are extended along geographical zones (Table 1; Figure 1).

There are more than ten sandalwood landraces in the form of both planted and naturally regenerated stands. However, study was only conducted at seven landraces in Gunung Sewu which were having a clear history of establishment, naturally regenerated, able to reproduce sexually, and representing each of geographical zones. For Gunung Sewu regions, observation was made on three of sandalwood landraces (Bleberan, herein after refer to GSM1-Bleberan, GSM2-Mulo and GSM3-Wanagama) in the lowland of Middle Zone, two landraces (GSN1Nglanggeran and GSN2-Sriten) in the highland of Northern Zone, one (GSN3-Bejiharjo) in the lowland of Northern Zone, and two (GSS1-Petir and GSS2-Botodayakan) in the karst area of Southern Zone of Gunung Sewu, respectively (Table 1; Figure 1). Each of Gunung Sewu Zones is separated by 25 to $40 \mathrm{~km}$, but landraces within zone are separated by less than $10 \mathrm{~km}$, with exception for Bejiharjo which is separated by more than $30 \mathrm{~km}$ away from any other landraces.

In order to determine the population structure and genetic parameter differences between the Gunung Sewu populations and those of its origin, this study also compared to the population and genetical data of sandal trees origin in Timor and Sumba Islands. It covered the remnant of the heavily harvested populations in Timor (the lowland of Soe, Tm-Soe) and Sumba (Sb-Sumba) islands, and the seed production area in the highland of Netpala (Tm-Netpala), Timor island. The data was gained from the previous researches (Ratnaningrum and Indrioko 2014, 2015, 2016; Indrioko and Ratnaningrum 2015a, b). In addition, the secondary (additional) data was collected 
Table 1. The landscape and habitat characteristics of sandalwood populations

\section{Population, width, altitude, climatic types}

GSN1-Nglanggeran;

79.3 ha; $710-750 \mathrm{~m}$ asl; Am type

GSN2-Sriten;

25 ha; 750-890m asl; Am type

GSN3-Bejiharjo;

$9.6 \mathrm{ha} ; 150-180 \mathrm{~m}$ asl; Aw type

52.9 ha; 150-170m asl

intermediate between

$A w$ and $A m$ type

\section{GSM2-Mulo;}

less than $1 \mathrm{ha} ; 150 \mathrm{~m}$ asl;

intermediate between

$A w$ and $A m$ type
Landscape history and present habitat characteristics

A part of Nglanggeran Formation, Northern Zone of Gunung Sewu. Now it exists as the strong undulating mountainary landscapes, characterizing tropical mountain ecosystems.

A part of Semilir Formation, Northern Zone of Gunung Sewu. Now it exists as the strong undulating highland landscapes, characterizing tropical mountain ecosystems, and is isolated by mountainary physical barriers.

A part of Sambipitu Formation, Northern Zone of Gunung Sewu. Now it exists as the open dry-rocky hilly landscapes with caves and ground-rivers below. Representing the dryland ecosystems.

A part of Wonosari Basin Formation, Middle Zone of Gunung Sewu. Now it exists as the catchment area of the ancient subterranean Oya River at the lowland basin andscapes. Representing the tropical lowland ecosystems.

A part of Wonosari Basin Formation, Middle Zone of Gunung Sewu. Now it exists as the limestone cliffs landscapes. Isolated by cliffs barriers.
Soil and rock units

Sandalwood history and

\section{present population characteristics}

Latosols with volcanic and Sandalwood was first documented in 1970's. Recently it occurs in groups of

sediment rocks, some with stands across the Nglanggeran mountain regions, in association with the

deeper solum.

tropical mountain vegetation. Habitat isdominated by the association of naturally regenerated mahogany, Gliricidea sp, and several Garcinia and Eugenia families.

Latosols with volcanic and Sandalwood was first documented in 1960's. Recently it covers three biggest sediment rocks, mostly with deeper solum. hills in an association with the tropical highland vegetation. Habitat is dominated by the association of naturally regenerated mahogany, Gliricide $\mathrm{sp}$, and several Garcinia and Eugenia families, and isolated by mountain physical barriers.

The association of red mediterrans and black grumosols with limestone rocks, mostly with the shallow solum

The association of red mediterrans and black grumosols with limestone rocks, mostly with the deeper solum.

Sandalwood is a remnant of the 1970's planted stands. Fragmented due to heavy exploitation, urban and cave-tourism activities since 1990's. Now, it exists as a small-fragmented group of stands, and dispersely occurs in an open dry-rocky hills above the caves and ground-rivers. Sandalwood grows in an association with cajuputi and acacia regenerated from commercial plantation nearby. Younger sandal trees are largely derived from root suckers. Sites are dominated by dryland herbs such as grasses and Eupatorium sp.

Sandalwood was first documented in 1970's along the catchment area of the ancient subterranean Oya River, at the lowland basin of middle zone. Sandalwood is dispersed widely along the riparian catchment area and nearby, in association with the tropical lowland forest vegetation which consists of more diverse vegetation including teak, mahogany, Gliricidea sp, Schleicera sp, cajuputi and acacia. Population is surrounded by several ex situ conservation areas, sharing the same river.

Latosols with limestone rocks, mostly with a very shallow solum.
Limestone cliffs ecosystems. Sandalwood was first documented in 1970's in the naturally regenerated stands surrounding the cliffs and nearby. Recently, small groups of sandalwood grow on the cracks of vertical limestone cliffs, at $3 \mathrm{~m}$ to more than $50 \mathrm{~m}$ belowground. 
GSM3-Wanagama;

$6 \mathrm{ha} ; 150-170 \mathrm{~m}$ asl; intermediate

between $A w$ and $A m$ type

GSS1-Petir;

78 ha;

70-100m asl; Aw type

GSS2-Botodayakan; 6.75 ha;

$100 \mathrm{~m}$ asl;

Aw type

Tm-Soe; approx. 10 ha;

$200 \mathrm{~m}$ asl; Strong Aw type

Tm-Netpala; 4.09 ha;

$1090 \mathrm{~m}$ asl;

Aw type

Sb-Sumba; Strong Aw type
A part of Wonosari Basin Formation, Middle Zone of Gunung Sewu. Now it exists as the lowland basin landscapes.

A part of Wonosari-Punung Karst Formation, Southern Zone of Gunung Sewu. Now it exists as the karst hilly landscapes with open dry-rocky hills, strong undulating, characterizing the dry rockylimestone ecosystems.

A part of Wonosari-Punung Karst Formation, Southern Zone of Gunung Sewu. Now it exists as the karst hilly landscapes surrounded by a very dense teak forest, less undulating. The flat basin areas were bordered by the rocky-hills slopes barriers.

Savanna landscapes in the lowland arid region of the southern part of Timor island. Previously it was sandalwood natural forests comprised more than 100 ha. Now it exists as a remnant of the heavily wildharvested population.

Seed production area in the highland arid region of Timor island. Less undulating, characterizing a highland arid ecosystem.

Sandalwood rehabilitated stands, using seedlings from Sumba, planted in the savanna landscapes in the middle region of Timor island.
Latosols with limestone rocks, mostly with deeper solum; well-managed.

Latosols with limestone rocks. Solum is deeper at the basins, but very

shallow at the limestone rocky hills.

Latosols with limestone rocks, mostly with deeper solum.

Red mediterrans soils, mostly with the shallow solum.

Ustic cambisol soils, mostly with the deeper solum.

Red mediterrans soils, mostly with the shallow solum.
Sandalwood was first introduced in 1967 using the seedlings from Timor. Ex situ conservation area is established in 1992-1993, consisting of seven provenances of Timor and Java Islands. Site is a part of Wanagama Forest Research Station which belongs to Universitas Gadjah Mada, well-managed for research activities.

Sandalwood was first documented in 1960's in karst hilly areas, recently covering more than twenty open dry-rocky hills. Adult plants were mostly derived from root suckers. In the open-undulating areas, sandalwood grows in association with dry rocky-limestone vegetation including acacia and cajuput, but is dominated more by shrubs and herbs such as grasses and Eupatorium sp.

Sandalwood was first documented in 1970's in karst hilly areas. Recently, small group of sandals grows in an association with dry-lowland forest vegetation, and is shaded by very dense teak canopies. Population is surrounded by a very dense teak forest and was bordered by the rocky-hills slopes barriers.

Previously, it was sandalwood natural forests comprised more than 100 ha. Now it exists as a remnant of the heavily wild-harvested population. Sandalwood occurs in dispersed small groups of ramets, is heavily clonalized, and grows in an association with the lowland arid savanna vegetation.

Sandalwood seed production area is established in 1992-1993, consists of six provenances of Timor. It is located in the highland arid region in the middle part of Timor island. It is well-managed for seed production purpose.

Planted in 2013 with genetic materials collected from the remnant of sandalwood natural forests in the Sumba island. Now it exists as the three years old saplings of sandalwood rehabilitated plantation in Kupang, Timor island. 
from the annual reports of local forestry agencies and personal communication with key persons. Both Timor populations are separated by more than $50 \mathrm{~km}$. Timor and Sumba Islands are separated by approximately $1000 \mathrm{~km}$. Whilst, Timor and Java Islands are separated by more than $3500 \mathrm{~km}$ in distance (Figure 1). Timor and Sumba Islands are located in the south-eastern parts of Indonesian archipelagos. These islands represent arid regions with strong $A w$ climatic type, characterized by long drought, particularly at lower altitude. The altitude varies between $100 \mathrm{~m}$ to more than $2000 \mathrm{~m}$ asl. Following heavy exploitation which has had occurred since 1900's, recently there are only a few individuals remained, dispersed in small groups of stands. Conservation efforts have been made by establishing some of the rehabilitated stand, in situ and ex situ conservation areas, but most of them were constructed by the unknown sources of genetic materials, and therefore resulted in a very low survival rate (Anonymous 2012; Indrioko and Ratnaningrum 2015b).

Our previous study found a variation of population structures and genetic parameters among sandalwood populations in Gunung Sewu (Java Island), Timor and Sumba Islands (Ratnaningrum et al 2015; Table 2).

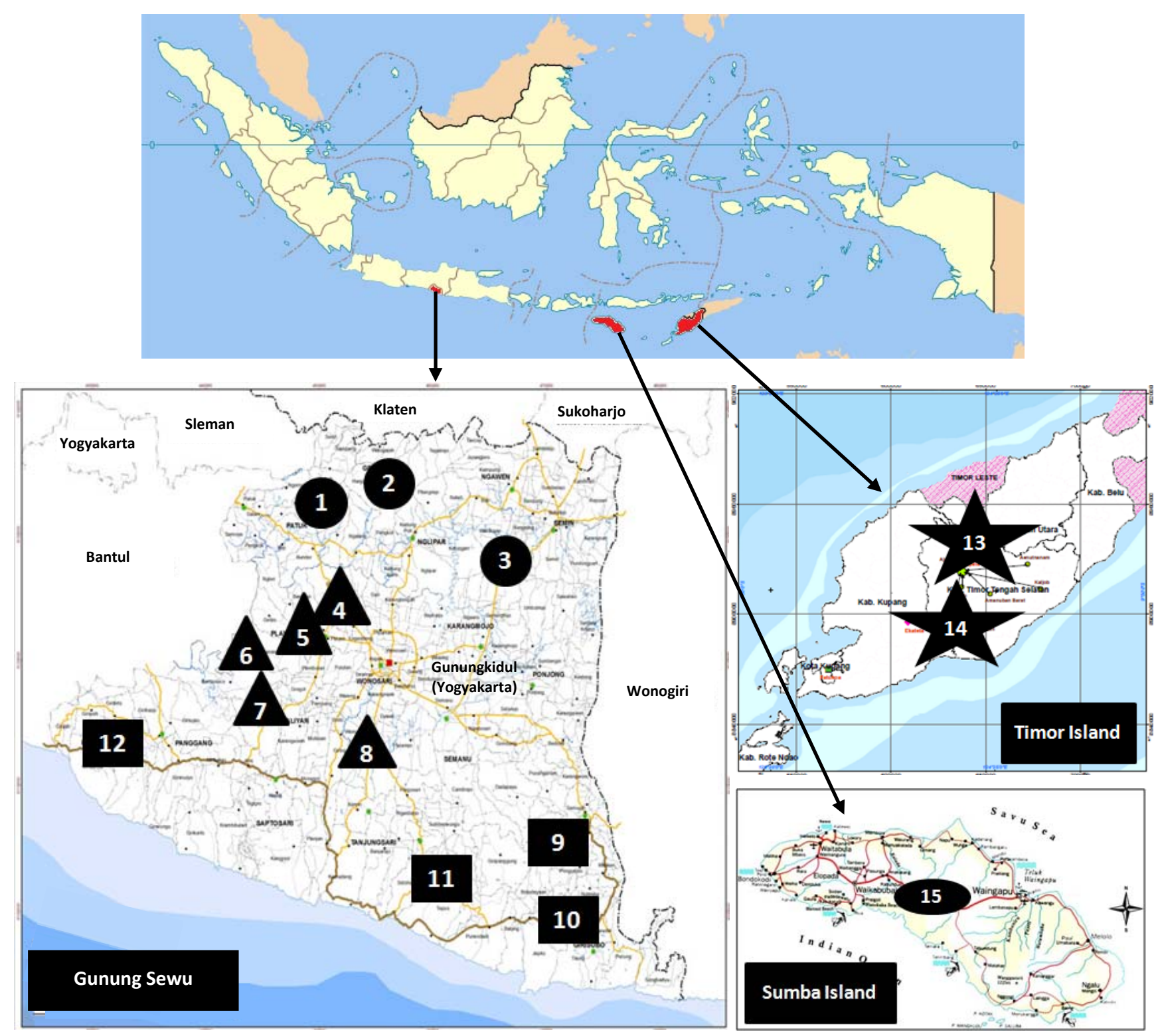

Figure 1. Study sites: sandalwood landraces in the Gunung Sewu Geopark, Java Island. The Gunung Sewu groups: the first group (Northern Zone): Nglanggeran (1), Sriten (2) and Bejiharjo (3); the second group (Middle Zone): Bunder (4), Wanagama (5), Banyusoco (6), Bleberan (7), and Mulo (8); and the third group (Southern Zone): Petir-Semugih (9), Botodayakan (10), Panggang (12) and Tepus (11) landraces, respectively. Within each Gunung Sewu zone, the landraces are marked by circles (Northern Zone), triangles (Middle Zone) and squares (Southern Zone) shapes, respectively. For comparison, the data was also obtained from sandalwood origin in Sumba Island (Sb-Sumba population, 15) and Timor Island (Tm-Soe population, 14 and Tm-Netpala seed production area, 13), respectively. 
Table 2. Population structures, number of individuals, and genetic parameters measurements on eleven sandalwood populations in Gunung Sewu (Java Island), Timor and Sumba Islands (Ratnaningrum et al 2015)

\begin{tabular}{|c|c|c|c|c|c|c|c|c|c|c|}
\hline \multirow{2}{*}{ Population } & \multicolumn{2}{|c|}{ Number of individuals } & \multicolumn{2}{|c|}{$\begin{array}{l}\text { Population } \\
\text { structures }\end{array}$} & \multicolumn{2}{|l|}{$\mathbf{H}_{\mathbf{e}}$} & \multicolumn{2}{|l|}{$\mathbf{H}_{\mathbf{o}}$} & \multicolumn{2}{|l|}{$\mathbf{F}_{\text {IS }}$} \\
\hline & Adult* & Seedling* & $\begin{array}{l}\text { Clona- } \\
\text { lity (\%) }\end{array}$ & $\begin{array}{l}\mathrm{N}_{\mathrm{e}} \\
(\%)\end{array}$ & Par. & Off. & Par. & Off. & Par. & Off. \\
\hline \multicolumn{11}{|l|}{ Gunung Sewu: } \\
\hline GSN1-Nglanggeran & $1145(50)$ & $93(39)$ & 24.02 & 12.31 & 0.269 & 0.231 & 0.261 & 0.284 & 0.029 & -0.231 \\
\hline GSN2-Sriten & 330 (119) & $50(26)$ & 20 & 15.76 & 0.308 & 0.296 & 0.317 & 0.348 & -0.031 & -0.175 \\
\hline GSN3-Bejiharjo & $496(116)$ & $124(23)$ & 76.62 & 18.55 & 0.315 & 0.210 & 0.312 & 0.102 & 0.008 & 0.514 \\
\hline GSM1-Bleberan & $1834(99)$ & $364(205)$ & 34.35 & 7.03 & 0.282 & 0.308 & 0.294 & 0.333 & -0.042 & -0.079 \\
\hline GSM2-Mulo & $41(35)$ & $12(0)$ & 12.19 & 41.46 & 0.259 & NA & 0.243 & NA & 0.062 & NA \\
\hline GSM3-Wanagama & $276(120)$ & $78(41)$ & 0 & 76.45 & 0.347 & 0.375 & 0.406 & 0.439 & -0.172 & -0.171 \\
\hline GSS1-Petir & $9190(55)$ & $2945(52)$ & 77.48 & 50.92 & 0.210 & 0.219 & 0.153 & 0.117 & 0.271 & 0.464 \\
\hline GSS2-Botodayakan & $151(29)$ & $72(50)$ & 25.83 & 17.22 & 0.367 & 0.306 & 0.324 & 0.313 & 0.117 & -0.025 \\
\hline \multicolumn{11}{|l|}{ Timor: } \\
\hline Tm-Soe & NA (21) & NA $(0)$ & 80 & NA & 0.044 & NA & 0.016 & NA & 0.638 & NA \\
\hline Tm-Netpala & $344(30)$ & NA (0) & 0 & 63.95 & 0.240 & NA & 0.193 & NA & 0.197 & NA \\
\hline \multicolumn{11}{|l|}{ Sumba } \\
\hline Sb-Sumba & NA (25) & NA (25) & 80 & NA & NA & 0.209 & NA & 0.163 & NA & 0.223 \\
\hline
\end{tabular}

Note: $N_{a}=$ the mean number of allele per locus, $P P L=$ the proportion of polymorphic loci, $\mathrm{H}_{\mathrm{e}}=$ Hardy-Weinberg expected panmictic heterozygosity, $\mathrm{H}_{0}=$ observed heterozygosity, $\mathrm{F}_{\text {is }}=$ mean fixation index over all loci, the deviation from expected frequencies under Hardy-Weinberg equilibrium, Par. $=$ Parents level, Off. $=$ Offsprings level. NA $=$ Not Assessed; * $=$ number in parentheses is the amount of sampled individuals

\section{Study species}

Sandalwood is a long-lived, yearly flowering perennial of semi-arid and tropical region throughout south-eastern and middle parts of Indonesia. It is a shrub attaining a height of about $12 \mathrm{~m}$ and a girth of 10 to $30 \mathrm{~cm}$ (Rao et al. 2007; da Silva et al. 2016). It is entomophilous and often produced abundant flowers (Warburton et al. 2000; Tamla et al. 2012). Flowers are arranged in inflorescences consisted of 20 to 40 small-red single flowers. Generally, in Indonesia, sandalwood flowered twice a year: at the beginning of dry season in May to September, and at the beginning of rainy season in November to March, with 4 to 5 months flowering period. The previous study showed evidence of dichogamy in which pollen matures two days before stigma receptivity (Ratnaningrum and Indrioko 2014, 2015). Studies on sandals' mating systems have indicated highly outcrossing rate and self-incompatibility (Sindhu-Vereendra and Anantha-Padmanabha 1996; Tamla et al. 2012; da Silva et al. 2016). However, partially selfcompatibility has also been reported for S. accuminatum (Warburton et al. 2000) and S. album (Suma and Balasundaran 2003; Ratnaningrum and Indrioko 2015), particularly under isolated condition. Despite its abundant flowers, the fruit production is very low (Sindhu-Vereendra and Anantha-Padmanabha 1996; Warburton et al. 2000; Tamla et al. 2012; Ratnaningrum and Indrioko 2016; da Silva 2016). Several studies reported high pollen fertility $(88.4 \%)$ in S. album in India (Sindhu-Vereendra and Anantha-Padmanabha 1996); and high rate of pollination effectiveness (10 to $40 \%)$ in S. album in Java Island (Ratnaningrum and Indrioko 2015). However its reproductive success was very low, ranging from less than
5\% in small populations (Sindhu-Vereendra and AnanthaPadmanabha 1996; Warburton et al. 2000; Byrne et al. 2003; Indrioko and Ratnaningrum $2015 \mathrm{~b}$ ) to about $20 \%$ in the bigger and wider genetic bases' populations (Ratnaningrum and Indrioko 2015; da Silva 2016). Sandalwood is mainly vegetatively reproduced by root suckers; the vegetatively propagated sproutings emerged from the horizontal roots, particularly under marginal condition (Warburton et al. 2000; Lhuillier et al. 2006; Dani et al. 2011; Herawan et al. 2014; da Silva et al. 2016). The clonality event may occur when most of off-springs in population were derived from a genetically identical individual, such a condition which has dramatically increased the level of selfing (Warburton et al. 2000; Charpentier et al. 2002; Indrioko and Ratnaningrum 2015a, b).

\section{Procedures \\ Isozyme analysis}

Genetic diversity was measured spatially across eleven landraces along geographical gradients in Gunung Sewu (Java Island), and several populations in Timor and Sumba Islands. To measure genetic diversity, at the beginning of rainy season in December 2015, juvenile leaves were sampled from randomly chosen individuals (N 208 individuals at GSN1-Nglanggeran, 110 at GSN2-Sriten, 104 at GSN3-Bejiharjo, 305 at GSM1-Bleberan, 35 at GSM2-Mulo, 161 at GSM3-Wanagama, 121 at GSS1-Petir, 129 at GSS2-Botodayakan, 57 at Netpala, and 21 at Soe). The flowering trees were of the first priority to be sampled.

Samples were wrapped, frozen in ice packs and taken to the laboratory for allozyme extraction and electrophoresis. 
Previous study gained three enzymes, shikimate dehydrogenase (E.C. 1.1.1.25.), esterase (E.C. 3.1.1.) and diaphorase (E.C. 2.6.4.3.) which observed to be polymorphic. Zymogram phenotypes that were interpretable were found for only six loci, shikimate dehydrogenase Skd-1, esterase Est-1, Est-2, and Est-3, and diaphorase Dia-1 and Dia-2 (Indrioko and Ratnaningrum 2015a; 2015b). Electrophoretic procedures were conducted with vertical polyacrylamide gel electrophoresis procedures following David-Ornstein method (Nei 1987). The leaves were homogenized in modified extraction buffer and centrifuged at $15,000 \mathrm{rpm}$ for $20 \mathrm{~min}$ at $0^{0} \mathrm{C}$. The supernatant was loaded onto polyacrylamide vertical slab (Sigma Inc., USA) gels and electrophoresed at $0^{\circ} \mathrm{C}$ at 220 $\mathrm{V}$ and $100 \mathrm{~mA}$ current for about $3 \mathrm{~h}$. After electrophoresis, the gels were stained using staining solution of each enzyme system, and the allozyme gels were genetically interpreted.

\section{Measuring genetic differentiation, genetic distance and migration rate}

At each of the allozyme locus, the frequency of each allele and the genotype were counted. The expected heterozygosity within population $\left(\mathrm{H}_{\mathrm{S}}\right)$ for each locus and over all loci for each population in Hardy-Weinberg equilibrium was counted following the formula, $\mathrm{H}_{\mathrm{S}}=1-\Sigma$ $p_{i}^{2}$, where $p_{i}$ refers to the $i$ 's allele frequency of a given population. Total population heterozygosity $\left(\mathrm{H}_{\mathrm{T}}\right)$ was counted following the formula: $\mathrm{H}_{\mathrm{T}}=1-\Sigma p_{i t}{ }^{2}$, where $p_{i t}$ refers to the $i$ 's allele frequency of the populations in total. To measure genetic differentiation, genetic diversity between population $\left(\mathrm{D}_{\mathrm{ST}}\right)$ was calculated by reducing the value of total heterozygosity $\left(\mathrm{H}_{\mathrm{T}}\right)$ to heterozygosity within a population $\left(\mathrm{H}_{\mathrm{S}}\right)$. The mean proportion of total gene diversity at polymorphic loci due to differences between populations $\left(\mathrm{G}_{\mathrm{ST}}\right)$ was measured by dividing $\mathrm{D}_{\mathrm{ST}}$ to $\mathrm{H}_{\mathrm{T}} I$, the genetic identity, was calculated following the formula, $I$ $=\left(\Sigma x_{i} y_{i}\right) / \sqrt{ }\left(\Sigma x_{i}^{2} \Sigma y_{i}^{2}\right)$, where $x_{i}$ refers to the i's allele frequency of the $x$ population, and $y_{i}$ is the $i$ 's allele frequency of the $y$ population. Genetic distance between pairs of populations $(D)$ was calculated following the formula, $D=-\ln I$. Based on the Nei's genetic distances between pair-wise populations, cluster analysis was performed following UPGMA algorithm and a dendrogram was then constructed (Nei 1987). Migration rate $\left(\mathrm{N}_{\mathrm{e}} \mathrm{m}\right)$, the level of previous gene flow which contributed to the recent population structure, was counted following the formula, $\mathrm{N}_{\mathrm{e}} \mathrm{m}=\left(1 / \mathrm{G}_{\mathrm{ST}}-1\right) / 4$ (Frankham et al. 2002).

\section{RESULTS AND DISCUSSION}

\section{Results}

\section{The migration rate, evidence of selection and genetic differentiation}

Gene flow among populations was determined by measuring $\mathrm{N}_{\mathrm{e}} \mathrm{m}$, the level of previous gene flow which contributed to the recent population structure (Table 3). GSM3-Wanagama, the most central population which also shares the same river with GSM1-Bleberan and several ex situ conservation areas nearby, tended to disperse seeds through both biotic agents and the stream flows. The seeds are widely dispersed by birds, in addition, some of seed deposits were observed along the river catchment areas in this study. Gene flow is largely occurred between GSM3Wanagama and GSM1-Bleberan populations $\left(\mathrm{N}_{\mathrm{em}}\right.$ Wanagama-Bleberan 48 individuals per generation). However, low migration rate among populations within this Middle Zone ( $\mathrm{N}_{\mathrm{em}}$ GS-Middle Zone only 3 individuals) indicated the restricted gene flow, probably due to the significantly different landscape and genetic structures of GSM2-Mulo population.

Gene flow is larger within the Northern Zone populations ( $\mathrm{N}_{\mathrm{em}}$ GS-Northern Zone 19 individuals), showed clear evidence of inheritance between GSN2-Sriten and GSN3-Bejiharjo. Whilst, migration is restricted between the two of Southern Zone populations $\left(\mathrm{N}_{\mathrm{em}}\right.$ GSSouthern Zone only 3 individuals) despite their shorter distance (only separated $5 \mathrm{~km}$ away), it is probably due to the differences in the degree of isolation and genetic base. Overall, each zone of Gunung Sewu exchanged 3 individuals per generation, which is more or less similar to the gene flow observed between Timor and Sumba Islands. However, the gene flow between populations within Timor island, as well as those observed between Gunung Sewu (Java Island) and Timor-Sumba islands, is strongly restricted, since none of individuals were exchanged.

The evidence of selection was detected by measuring the allelic richness within populations (Table 3). As has discussed, the rare and missing alleles can be the indicator of bottleneck effects and genetic drifts, which might occur as a result of selection events. In this study, the highly genetically differentiated populations, which are in many cases related to the restricted gene flow, generally possessed a lower allelic richness and lost more alleles. The highly differentiated and restricted populations in Timor showed lowest level of allelic diversity $\left(\mathrm{N}_{\mathrm{a}}\right.$ 1.91, PPL 0.67 ), while those of Gunung Sewu were somewhat higher $\left(\mathrm{N}_{\mathrm{a}}\right.$ 2.30, PPL 0.91). The most connected populations in the Northern Zone of Gunung Sewu showed the most diverse alleles $\left(\mathrm{N}_{\mathrm{a}}\right.$ 2.36, PPL 0.97).

The Middle Zone populations in Gunung Sewu showed higher genetical differences than those of Northern Zone, and hence possessed lower allelic richness. These differences might attribute to the highly genetically and physically differentiated features of GSM2-Mulo, the cliff population. However, when GSM2-Mulo is removed from the measurements, the allelic richness of GSM3Wanagama and GSM1-Bleberan are the highest $\left(\mathrm{N}_{\mathrm{a}} 2.5\right.$, $P P L$ 1). Moreover, rare alleles were less, and none of these alleles were missing at both of populations. GSM3Wanagama, the most genetically diverse population, is the closest to GSM1-Bleberan with only less than $2 \mathrm{~km}$ of distance. Both populations experienced the similar environmental conditions, shared the same river, and possessed the highest migration rate $\left(\mathrm{N}_{\mathrm{e}} \mathrm{m} 48\right.$ individuals per generation). GSM2-Mulo, the highly isolated population, possessed much lower allelic richness $\left(\mathrm{N}_{\mathrm{a}} 2.0\right.$, $P P L$ 0.67, respectively). 
Table 3. The allelic richness, heterozygosity, genetic differentiation, and migration rate among populations of sandalwood, within and between islands of Java, Timor, and Sumba

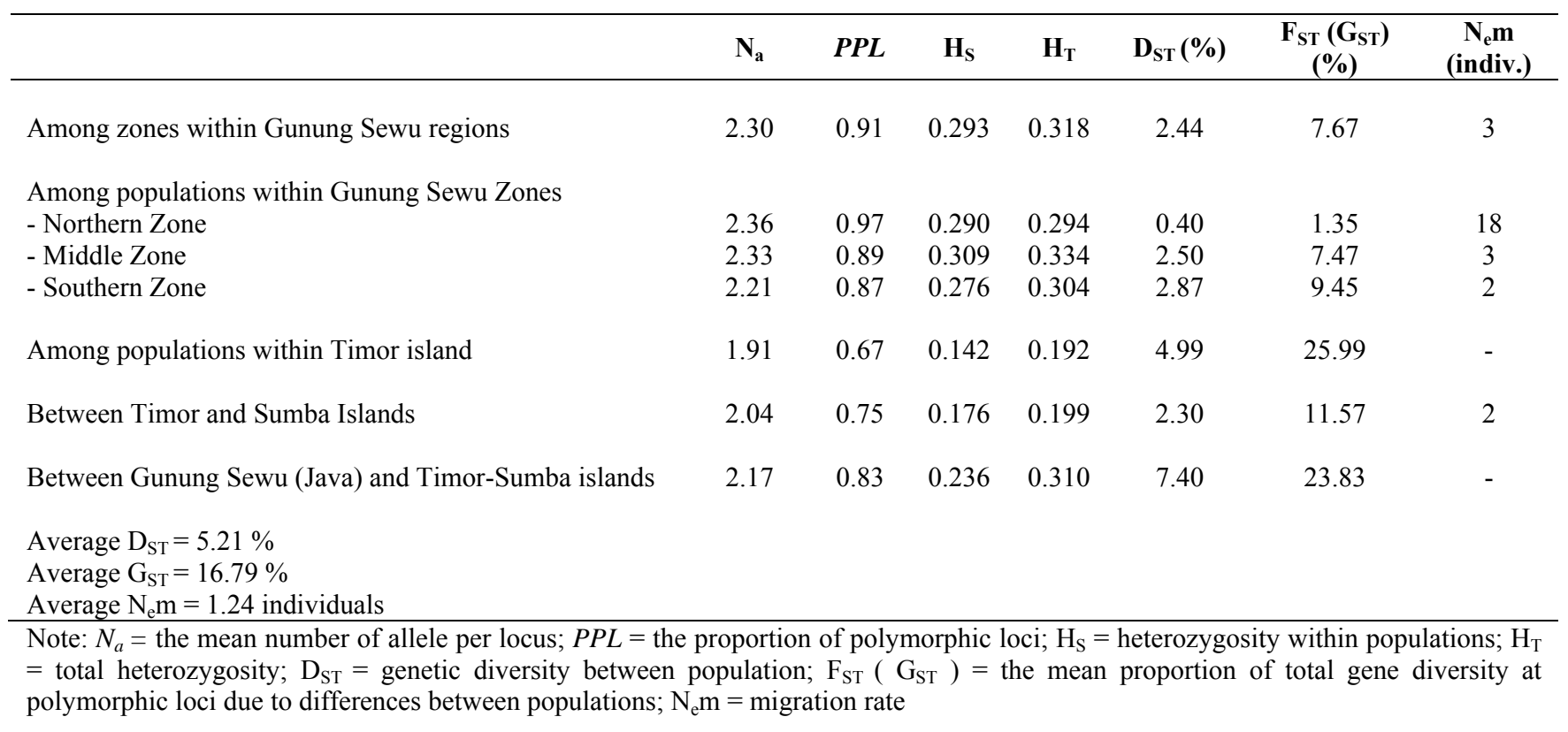

Genetic differentiation among populations. In general, the heterozygosity among populations $\left(\mathrm{D}_{\mathrm{ST}}\right)$ was very low (Table 3). Within Gunung Sewu regions, only $2.44 \%$ of total heterozygosity existed due to the differences among populations. The three of populations within Northern Zone of Gunung Sewu performed very low diversity ( $D_{\mathrm{ST}}$ GSNorthern Zone only $0.39 \%$ ); whereas the three of Middle Zone populations showed higher diversity $\left(\mathrm{D}_{\mathrm{ST}} \mathrm{GS}-\right.$ Middle Zone $2.49 \%$ ) than those of Northern Zone. In contrast to the higher diversity of populations within Timor island $\left(\mathrm{D}_{\mathrm{ST}}\right.$ Timor $\left.4.99 \%\right)$, the diversity between islands was somehow low $\left(\mathrm{D}_{\mathrm{ST}}\right.$ Timor-Sumba 2.30\%). The genetic diversity was highest between Gunung Sewu (Java Island) and Sumba-Timor islands, with $7.40 \%$ of total heterozygosity, due to the differences among islands.

The genetic differentiation, represented by $F_{\mathrm{ST}}$ or $\mathrm{G}_{\mathrm{ST}}$ (the mean proportion of total gene diversity due to differences between populations), ranged from $1.35 \%$ to 9.45\% among populations within zones in Gunung Sewu; $25.99 \%$ among populations within Timor island; $11.57 \%$ between Sumba and Timor islands; and 23.83\% between Gunung Sewu and the two of south-eastern islands. Genetic differentiation was highest between populations within Timor island $\left(\mathrm{G}_{\mathrm{ST}}\right.$ Timor $\left.25.99 \%\right)$, which was even higher than those of between Gunung Sewu (Java Island) and Sumba-Timor islands ( $\mathrm{G}_{\mathrm{ST}} \quad 23.83 \%$ ). Only $7.67 \%$ of genetical differences existed among populations within Gunung Sewu regions. GSN1-Nglanggeran, GSN2-Sriten and GSN3-Bejiharjo, which were the three populations within Northern Zone, performed low genetical differences ( $\mathrm{G}_{\mathrm{ST}}$ GS-Northern Zone only1.35\%).

GSM3-Wanagama, GSM1-Bleberan and GSM2-Mulo, the three of Middle Zone populations in Gunung Sewu, somehow showed higher genetical differences than those of
Northern Zone. GSM3-Wanagama is the closest station to GSM1-Bleberan with only less than $2 \mathrm{~km}$ of distance, and both populations also shared the same river. When GSM2Mulo is excluded from the measurements, the genetical differences between GSM3-Wanagama and GSM1Bleberan are very low $\left(\mathrm{D}_{\mathrm{ST}} 0.17 \%, \mathrm{G}_{\mathrm{ST}} 0.52 \%\right)$, and the migration rate is very high $\left(\mathrm{N}_{\mathrm{e}} \mathrm{m} 48\right.$ individuals per generation). Both populations are separated from GSM2Mulo by $15 \mathrm{~km}$ away. GSS1-Petir and GSS2-Botodayakan, the two of Southern Zone populations under karst ecosystem type, were also observed to show higher genetical differences $\left(D_{\text {ST }} 2.87 \%, G_{S T} 9.45 \%\right)$ due to the landscape and genetical base differences. In contrast to the higher genetic differences observed within Timor island $\left(\mathrm{D}_{\mathrm{ST}} 4.99 \%, \mathrm{G}_{\mathrm{ST}} 25.99 \%\right)$, these differences were somehow low between islands $\left(\mathrm{D}_{\mathrm{ST}} 2.30 \%, \mathrm{G}_{\mathrm{ST}} 11.57 \%\right.$ between Timor and Sumba island).

\section{Genetic distance}

The dendrogram indicated a grouping of populations into three clusters. Populations within the same cluster expressed a high portion of same alleles and genotypes. The genetic similarity may be contributed to their similarity on the genetical and reproductive processes controlled by the landscapes structures and parental genetic base. However, there seemed to be less associative between geographical and genetic distance. Dendrogram clearly showed evidence that the populations were not clustered based on their geographical sites of occurrence, but more by their similarity on population structures with regard to the parental genetic base, degree of fragmentation and clonality.

In general, the more continuous, bigger and wider genetic-bases' populations allowed larger gene flow and 
higher outcrossing rate. Moreover, the population structures similarity on the less clonalized conditions and higher parental heterozygosity led to a lower genetic differentiation, as it was reported on GSN1-Nglanggeran, GSN2-Sriten, GSM1-Bleberan, GSM3-Wanagama and GSS2-Botodayakan, which were grouped into the same cluster ( $D$ ranged from 0.008 to 0.032 ). Among populations within this cluster, GSN2-Sriten and GSS2-Botodayakan was separated along north to south gradient of more than $60 \mathrm{~km}$ away, and occupied significantly different geographical, altitudinal and ecological features. However, the genetic distance is surprisingly very close.

In contrary, the fragmented and isolated populations experienced lower gene flow and tended to have more inbreeding mating system, which led to the different genetical and reproductive processes, and therefore were significantly differentiated. This was a case with Tm-Soe, Tm-Netpala, GSN3-Bejiharjo and Sb-Sumba which were in the same clusters ( $D$ ranged from 0.005 to 0.024 ). In average, the first and second groups had a mean genetic distance $(D)$ of 0.040 . Another cluster consisted of two populations, GSM2-Mulo and GSS1-Petir ( $D$ 0.054). Both populations were located at the different zone of Gunung Sewu, and separated by more than $40 \mathrm{~km}$ in distance, and had different landscape and environmental types. GSS1Petir seemed to be genetically farther apart from the rest of sandal populations due to the differences in the history of disturbance, degree of clonality and parental genetic base.
Hence this population remained isolated and couldnot be linked to any other groups due to its genetical differences ( $D$ ranged from 0.094 to 0.149 ). In the case of GSM2Mulo, the most isolated cliff landscape conditions were responsible for this genetical differences ( $D$ ranged from 0.068 to 0.117$)$.

\section{Discussion}

\section{Gene flow among populations}

Fragmented and/or isolated conditions may result in a lack of gene flow and seed dispersal (Warburton et al. 2000; Lhuillier et al. 2006; Dani et al. 2011). Sandalwood performs outcross-mating and to avoid inbreeding depression they require sufficiently large populations for gene flow. Clear clustering on some of sandal populations regarded to their landscape differences, suggested that gene flow and outcrossing opportunities might have been restricted to those isolated populations. Gene flow via seed dispersal needs seed dispersers being both biotically agents such as birds or humans, and the abiotic ones such as water. In some cases, suitable habitats for sandalwood in the three zones of Gunung Sewu, as well as those of Timor and Sumba Islands, are spatially isolated, particularly those which experienced fragmentation for urban activities or natural barriers. Such an isolation will not be able to maintain a larger gene flow.

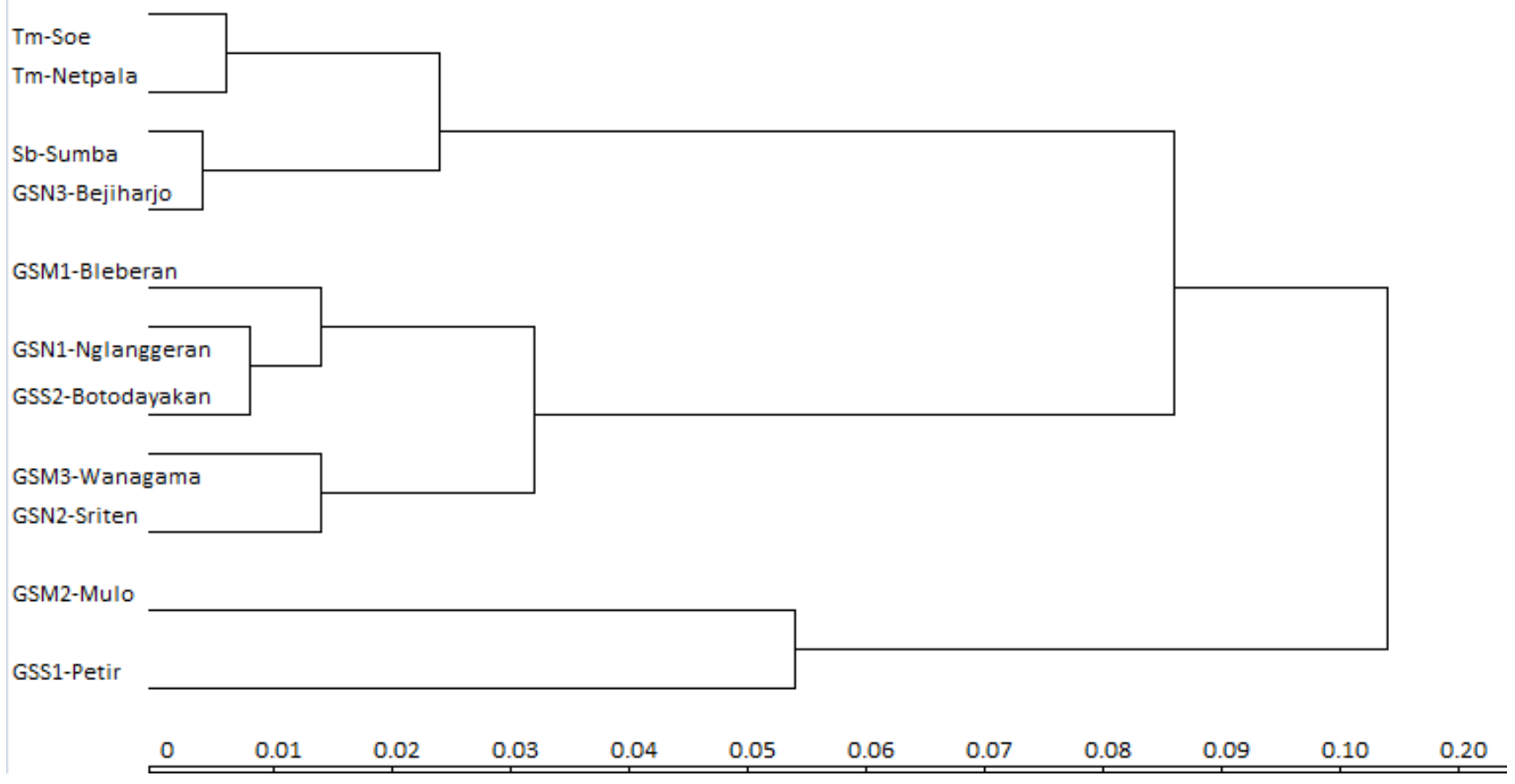

Figure 2. Dendrogram analysis for eleven sandalwood populations at different landscapes in Gunung Sewu (Java Island), Timor and Sumba Islands 
A possible explanation for the low genetic differentiation, and in addition, a relatively high seedling recruitments, may be related to the pattern of dispersal by birds. Low genetic differentiation and more seedling recruitments were observed in populations which provide suitable environments for bird activities, such as GSM3Wanagama, GSS2-Botodayakan and GSN2-Sriten which are surrounded by dense woody stands. Gene flow through pollen dispersal would be expected to be low in sandalwood as it is insect-pollinated (Sindhu-Vereendra and Anantha Padmanabha 1996; Dani et al. 2011), with optimum pollen distance is only $42 \mathrm{~m}$ (Ratnaningrum and Indrioko 2014). Isolated and small populations in sandals may disturb pollen transfer by its effects on restricted pollinator movements (Sindhu-Vereendra and Anantha Padmanabha 1996; Dani et al. 2011), inadequate flowers for rewards (Tamla et al. 2012; Ratnaningrum and Indrioko 2014), insufficient quantity of outcross-pollen donor and the incompatible pollen (Warburton et al. 2000). Seed dispersal in sandals is moderate as the seeds are widely dispersed by birds with a wider range of distribution (Byrne et al. 2003; Bottin et al. 2007) which can reach more than 5 kilometers in the distance (Ratnaningrum and Indrioko 2014). The wind pollinated and/or the longdistance bird-dispersal seeds, as of sandals, showed a lower association between genetic and geographic distance (Warburton et al. 2000). The negative value of fixation index was also represented the outcrossing, long-lived perennial species which have seeds dispersed through ingestion by animals (Moreira et al. 2015). Additionally, some extent of dispersal by stream river flow was also observed, particularly between populations which share the same river. Five birds species, puyuh pepekoh (Coturnix chinensis), madu sriganti (Nectariana jugularis), cekakak sungai (Todirhampus chloris), kutilang (Pycnonotus aurigaster) and tekukur (Streptopelia chinensis), reported as the dispersal agents of sandalwood in Gunung Sewu (Ratnaningrum and Indrioko 2014). This agent was also known to break seed chemical-dormancy and facilitate seed germination by their ingestion.

In contrast to many other results which reported rivers as the physical barriers (Cursach et al. 2012; Moreira et al. 2015), the Oya River in the Middle Zone acted as connecting agents for seed dispersal. Our observation detected very low genetic differences and much larger gene flow between GSM1-Bleberan and GSM3-Wanagama which share the same river. Hence the connecting role of both riparian dynamics and birds communities support the idea of a larger gene flow within the Middle Zone populations.

Populations separated by less than $10 \mathrm{~km}$ are linked genetically through pollen flow (Cursach et al. 2012). However, in this study, gene flow is restricted among some of isolated populations, even when they were within the same geographical zone. This is considered to be the effects of habitat fragmentation and isolation due to the geographical barriers, for example in the cliff and mountain ecosystems, which might limit gene flow (Cursach et al. 2012; Garfi et al. 2013; Moreira et al. 2015). Genetic structuring due to the habitat isolation by natural barriers was also reported on Quercus macrocarpa under savanna barriers in Illinois (Craft and Ashley 2007), Lumnitzera littorea in the tropical Asian mangrove (Pautasso 2009), Santalum insulare under the island ecosystems in insular Pacific (Lhuillier et al. 2006), and S. album in GSM2-Mulo population under rocky limestone cliffs habitat in this study. However, the small and naturally isolated populations of GSN2-Sriten and GSS2-Botodayakan could maintain genetic diversity and outcross due to a higher genetic base.

\section{Evidence of selection}

The lower genetic diversity and higher inbreeding rate in some of clonalized and fragmented populations is an indication that the gene flow is already restricted and reproductive fitness is already disrupted, since selfincompatible species are more vulnerable to the negative effects of habitat fragmentation (Lutz et al. 2000; Torres et al. 2003). This result confirmed theoretical models that the fragmented and isolated populations tended to loose more alleles and have lower heterozygosity, which provides evidence for a potential genetic bottleneck effects (Garfi et al. 2013; Moreira et al. 2015). As has discussed, the rare and missing alleles are regarded as criteria for measuring loss of diversity due to genetic bottlenecks. As described in the Result Section, both allelic diversity and heterozygosity decrease with an increase of isolation, and these loss is much more greater at the offspring level than those of parental ones. The events of selection (Garfi et al. 2013; Moreira et al. 2015), as well as migration (Cursach et al. 2012) and/or mutation (Torres et al. 2003), might explain such a situation.

The ability of a population to respond to selection is directly related to the level of genetic variation available for relevant adaptive characters (Torres et al. 2003). Therefore it is considered that species with a narrow genetic base will not be able to respond to changes in environmental pressures. According to the allelic diversity and heterozygosity, more continuous and larger genetic bases of sandalwood populations could maintain a significant level of genetic variation in such a condition which supports larger gene flow and outcrossing.

\section{Genetic differentiation of sandalwood}

The relation between geographical and genetic distance. This highest genetical difference between populations within Timor island, which was even higher than those of between Gunung Sewu (Java Island) and Sumba-Timor islands, might be attributed to the differences in the parental genetic materials and the degree of disturbances between Netpala and Soe populations. Netpala was established using several provenances of Timor and is well managed for seed production purpose. Whilst, Soe is the remnant of heavily harvested population which was damaged since a very long period.

A lower genetical difference among the three populations within Northern Zone may relate to the history of occurrence of GSN3-Bejiharjo population. GSN3Bejiharjo population was introduced at 1970's with the unknown sources originated from Nglipar District, a site 
that is recently recognized as the GSN2-Sriten population (The Head of RPH Gelaran Bejiharjo, pers. comm.). This finding showed evidence that GSN2-Sriten was the ancestor of GSN3-Bejiharjo population in the past, and therefore both Northern populations shared the same allele frequencies and distributions. The differences of past condition from recent condition had a relation with the differences in landscapes structures and anthropogenic disturbances, which resulted in the different genetical processes. Another population in Northern Zone, the GSN1-Nglanggeran mountain, were connected to GSN2Sriten population and altogether formed the Batur Agung highland zones. Both GSN1-Nglanggeran and GSN2-Sriten were less disturbed, influenced by similar Am climatic type and the highland environment, and having similar soil types, and therefore were shared similar evolutionary and genetical processes.

It seemed that it is not the geographical distance which caused the genetic differences among the three of Middle Zone populations, as well as the two of Southern Zone populations in Gunung Sewu. This higher genetic differentiation was caused more by their differences on landscapes structures and parental genetic base. If GSM2Mulo, the cliff-isolated landrace, is included in the measurements, then the genetical differences is much higher $\left(\mathrm{D}_{\mathrm{ST}} 2.50 \%, \mathrm{G}_{\mathrm{ST}} 7.47 \%, \mathrm{~N}_{\mathrm{e}} \mathrm{m} 3\right.$ individuals per generation). On the other hand, differences were somehow lower between Timor and Sumba island. These findings revealed some evidence that both islands might share the same sources in the past, experienced similar evolutionary and disturbance histories, and therefore shared a large portion of same genes.

Many landscape-genetical based studies reported isolation and genetic differentiation by distance (Lhuillier et al. 2006; Bottin et al. 2007; Schmidt et al. 2009). However, differentiation among sandalwood populations was neither related to population size, nor to the geographic distance among populations. Grouping of population in dendrogram was not based on their geographical sites of occurence, but more by the similarity on clonality level and parental heterozygosity, which led to similar mating systems and reproductive processes. As reported in many cases, isolated species are more differentiated due to the restricted gene flow (Byrne et al. 2003; Pautasso 2009; Dani et al. 2011), the possible dominance of the founding event (Bottin et al. 2007; Garfi et al. 2013), the isolation from source populations (Lhuillier et al. 2006), and the stochastic processes due to their limited size (Botting et al. 2007; Moreira et al. 2015). Overall, the lack of a marked effect on differentiation to geographic distance indicates a dominant role of genetic drift relative to gene flow, as has also reported with sandalwood in other studies (Bottin et al. 2007; Schmidt et al. 2009; Garfi et al. 2013).

Similar result was also reported with Santalum insulare in Pacific islands where dendrogram did not clearly separate the archipelagos, and populations were grouped based on the similarity of genetic structures (Lhuillier et al. 2006). In S. australocaledonium in New Caledonia, some of highland and lowland populations were gathered on the same branch due to the low and non-significant $\mathrm{F}_{\mathrm{ST}}$ (Bottin et al. 2007). In a long-lived, monoecious tree species Quercus macrocarpa in the north eastern U.S., the savanna landscape barriers did not restrict gene flow, hence the differentiation among populations were not correlated to distance ( $\mathrm{F}_{\mathrm{ST}}$ 0.027) (Craft and Ashley 2007).

Timor and Indian S. album populations had a mean genetic distance $(D)$ of 0.447 , which is very large compared to intra-specific distances in other species (Brand 1994). The average of $D$ between western and eastern populations of Acacia albida in Africa was 0.273, and they were considered as different races (Brand 1994). In contrast, a very low genetic distance was observed in 16 populations of Quercus ilex along Mediterranean gradients (D only 0.023) (Craft and Ashley 2007). The continuous populations performed lower genetic distance, as reported in the connected populations of S. spicatum along Western Australia ( $D$ ranged from 0.006 to 0.073) (Byrne et al. 2003). While for S. australocaledonium in New Caledonia, the populations were strongly differentiated by the marked genetic drift, limited gene flow, and natural selection due to contrasted environment condition on the different geographical regions (Bottin et al. 2007).

The effects of population structures to the genetic differentiation. Landscape structures regarded to different rock outcrops, slopes and natural barriers may lead to the differences of the genetical and evolutionary processes within population (Torres et al. 2003). As reported in this study, the genetical difference among populations was related to the differences on landscapes structures and anthropogenic disturbances. More continuous, undisturbed and bigger population tended to exchange larger gene flow per generation. In contrast, gene flow was restricted in the isolated and disturbed populations. According to the $D$ and F $_{\text {ST }}$ values, GSS1-Petir and GSM2-Mulo appeared to be the most differentiated populations. The significant geographic barrier is the rocky limestone cliffs in GSM2-Mulo, which might have determined the genetic differentiation in the Middle Zone. The disjunct and isolated limestone cliff population of GSM2-Mulo is genetically different from others. Most of adult trees flowered abundantly, performed moderate level of diversity, and the inbreeding coefficient was closed to zero which indicated a random mating. However they failed to produce mature fruits due to the pollinators and pollination difficulties in the cliffs environments. Some of mature fruits might have survived, however the unavailability of seed beds on the dry, rocky vertical walls did not allowed the survived seeds to germinate. Genetic differentiation related to landscapes was also reported for many other species within a wider habitat range. Some of landscape features which may act as geographic barriers are rivers (Moreira 2015) and cliffs (Cursach et al. 2012; Garfi et al. 2013; Hmeljevski et al. 2014; Agullo et al. 2015). For example, in Saxifraga aizoides, large spatial gaps existed between small remnant populations within regions, resulted in the considerable genetic differentiation (Lutz et al. 2000). Pollinator and pollination limitation were also reported with Ranunculus weyleri under cliff granitic rocks environment, resulted in a very low reproductive success (Cursach et al. 2012). 
The genetic differentiation is considered high when $\mathrm{G}_{\mathrm{ST}}$ $>30 \%$ (Young et al. 2001). In this study, the $\mathrm{G}_{\mathrm{ST}}$ was highest between populations within Timor island $\left(\mathrm{G}_{\mathrm{ST}}\right.$ $25.99 \%$ ), which was even higher than those of between Gunung Sewu (Java Island) and Sumba-Timor islands $\left(\mathrm{G}_{\mathrm{ST}}\right.$ $23.83 \%$ ). Results on genetic differentiation were similar to S. insulare which experienced similar isolation and clonality problems (Lhuillier et al. 2006). In S. insulare, 58 $\%$ of the trees were clones, and the genetic structure was characterized by high levels of differentiation between archipelagos (27\% of the total variation) and islands $\left(\mathrm{G}_{\mathrm{ST}}\right.$ $50 \%$ ). RAPD-based study on the three small, fragmented populations of S. album in Southern India reported highly genetic structuring due to a restricted gene flow ( $F_{S T}$ $54.9 \%$ ) (Dani et al. 2011), a same case to those occurred in five isolated populations of S. lanceolatum in south-eastern Victoria $\left(D_{\mathrm{ST}} 19 \% ; \mathrm{F}_{\mathrm{ST}} 76 \%\right.$ ) (Warburton et al. 2000). In contrary, the more un-isolated and bigger populations allowed gene flow to occur among sites, and therefore they shared the same alleles and possessed lower genetic differentiation. Ten provenances of S. album in India and two in Timor performed lower level of genetic differentiation, indicated some extent of gene flow in the past $\left(\mathrm{F}_{\mathrm{ST}} 28.6 \%\right.$ and $17.2 \%$, respectively) (Brand 1994).

The highly varied $F_{\mathrm{ST}}$ due to the fragmentation differences, as reported in this study, was also observed with sandalwood in India (Rao et al. 2017). In the bigger and continuous populations of S. album in Peninsular India, a high gene flow occurred ( $\mathrm{F}_{\mathrm{ST}} 3.4 \%$ ) (Rao et al. 2007); in contrast to their counterparts in small, fragmented populations in Southern India which possessed highly genetic structuring due to a restricted gene flow $\left(\mathrm{F}_{\mathrm{ST}}\right.$ 54.9\%) (Dani et al. 2011). Similarly, S. spicatum in Western Australia, in which their undisturbed and bigger populations could maintained their equilibrium and gene flow, was reported to have a low value of $F_{\mathrm{ST}}(8.3 \%)$ and genetic distance ( $D$ 0.031) (Byrne et al. 2003).

The genetic structuring of plants in isolated habitats may also be influenced by the founder effects (Torres et al. 2003; Craft and Ashley 2007). From a historical perspective, particularly the Tm-Soe and GSS1-Petir populations have heavily disturbed and experienced founder events since a long time period (Indrioko and Ratnaningrum 2015b). This event may still dominate the genetic processes and lead to the low levels of recent genetic diversity. A very low genetic base due to long periods of heavy exploitation, which resulted in a high genetic differentiation, was also reported for Acacia nemorosa and A. columnaris in New Caledonia (Kettle et al. 2007), and the remnants of heavily harvested S. album in southern India (Dani et al. 2011). In other cases, genetic differentation due to many kinds of disturbances were observed in the Brazilian tropical dry forests fragments which were under severe human threats for a long time period (Moreira et al. 2015), the disturbed populations of Pinus squamata in tropical Yunnan of China (Zhang et al. 2005), the fragmented populations of Geum urbanum due to extensively agricultural activities in central Europe (Schmidt et al. 2009), and the isolated populations of $S$. lanceolatum due to grazing in south-eastern Victoria (Warburton et al. 2000).

The results of the study on several populations of sandalwood, which covers both $\mathrm{Am}$ and $\mathrm{Aw}$ environments across geographical gradients in Gunung Sewu (Java Island), Timor and Sumba Islands, suggested that (1) natural barriers contributed to the habitat fragmentation and disrupted gene flow among populations; (2) the gene flow affected selection processes regarding to the bottleneck effects and genetic drifts, which resulted in the differences in allelic richness and population diversity; and (3) the variation in gene flow and selection processes consequentially resulted in genetic differentiation among populations. Gene flow restriction and the considerable genetic drift occurred, particularly when the population had a lower genetic base, highly clonalized, fragmented, and/or several inbreedings in mating system. In contrast, more continuous, undisturbed and wider genetic bases' population tended to exchange larger gene flow per generation. Such populations also performed higher genetic diversity and outcrossing rate which minimized loss of rare alleles due to genetic drift. Some exceptions were also made for several isolated, but less-clonalized and higher genetic bases' populations, which were able to maintain higher genetic diversity and to outcross under gene flow restriction.

The genetic differentiation was highest between populations within Timor island, and between Gunung Sewu (Java Island) and Sumba-Timor islands. But there was less association between geographical and genetic distance. Populations were not clustered based on their geographical sites of occurrence, but more by their similarity of genetic structures. Genetic differentiations among sandalwood populations might be best explained by the combined effect of the differences on genetical processes, with regard to the gene flow and selection events. Both differences existed due to the differences in (i) population structures including landscape types, degree of clonality and genetic composition at parents level, and (ii) the disturbances histories of the population, which contribute to the equilibrium between gene flow and drift. This findings emphasized the importance of larger gene flow and populations' genetic base to naturally maintain the genetical processes of sandalwood population under various landscapes structures.

\section{ACKNOWLEDGEMENTS}

These results are part of Yeni W.N. Ratnaningrum's $\mathrm{Ph}$.D. research on sandalwood genetic conservation and improvement; which is supported by the grant of Hibah BPPS year 2012-2015, and the grant of Hibah Penelitian Disertasi Doktor year 2017, by Direktorat Jenderal Pendidikan Tinggi, Kementerian Pendidikan dan Kebudayaan Indonesia. The laboratory work and analyses were done at the Genetics Laboratory of Silviculture Department, Universitas Gadjah Mada in Yogyakarta, Indonesia, and we would like to express our gratitude to Professor Mohammad Na'iem as the head of the 
laboratory. Many thanks go to Untung Maryanto for laboratory works and Jito for greenhouse works. Our gratitude also go to Andiyanto (Nglanggeran), Sukarto (Sriten), Sunar (Bejiharjo), Kustini (Bleberan), Kardi (Mulo), Tukiyat (Wanagama), Suparsono (Petir and Botodayakan), Idwan S Wirakarsa and Rini Purwiastuti (Sumba, Soe and Netpala), and Mardi (Balai Penelitian Kehutanan, The Center of Forestry Research Kupang) for field assistances and data collections.

\section{REFERENCES}

Agullo JC, Perez-Banon C, Crespo MB, Juan A. 2015. Puzzling out the reproductive biology of the endangered cat's head rockrose (Helianthemum caput-felis, Cistaceae). Flora 217: 75-81.

Anonymous. 2012. Menanam kembali satu juta pohon cendana di NTT (The replanting of one million sandalwoods in Nusa Tenggara Timur). Ministry of Forestry, Republic of Indonesia. Jakarta, Indonesia. [Indonesian]

Bottin L, Tassin J, Nasi R, Bouvet J. 2007. Molecular, quantitative and abiotic variables for the delineation of evolutionary significant units: case of sandalwood (Santalum austrocaledonicum Vieillard) in New Caledonia. Conserv Genet. 8:99-109.

Brand JE. 1994. Genotypic variation in Santalum album. Sandalwood Research Newsletter. Issue 2-1994.

Byrne M, MacDonald B, Broadhurst L, Brand J. 2003. Regional genetic differentiation in Western Australian sandalwood (Santalum spicatum) as revealed by nuclear RFLP analysis. Theor Appl Genet 107:1208-1214, 2003.

Carpentier A. 2002. Consequences of clonal growth for plant mating. Evol Ecol 15:521-530.

Craft KJ, Ashley MV. 2007. Landscape genetic structure of bur oak (Quercus macrocarpa) savannas in Illinois. For Ecol \& Manag 239: 13-20.

Cursach J, Rita J. 2012. Reproductive biology of Ranunculus weyleri (Ranunculaceae), a narrowly endemic plant from the Balearic Islands with disjunct populations. Flora 207: 726-735. 2012.

Dani, K.G.S, Ravikumar, P., Kumar, R.P, Kush, A. 2011. Genetic variation within and among small isolated populations of Santalum album. Biologia Plantarum 55 (2): 323-326.

da Silva JAT, Page T, Zhang X, Kher MM, Nataraj M, Soner D, Ma G. 2016. Sandalwood: basic biology, tissue culture, and genetic transformation. Planta 243: 847-887.

Frankham R, Ballou JD, Briscoe DA. 2002. Introduction to Fores Genetics. Cambridge University Press. Cambridge, UK.

Garfì G, Mercati F, Fontana I, Collesano G, Pasta S, Vendramin GG, Michele R, Carimi F. 2013. Habitat features and genetic integrity of wild grapevine Vitis vinifera L. subsp. sylvestris (C.C. Gmel.) Hegi populations: A case study from Sicily. Flora 208: 538-548.

Harbaugh DT, Baldwin BG. 2007. Phylogeny and biogeography of the Sandalwoods (Santalum, Santalaceae): repeated dispersals throughout the Pacific. Am J Bot 94(6): 1028-1040. 2007.

Haryono E, Suratman. 2010. Significant features of Gunung Sewu Karst as geopark site. In Umar $\mathrm{H}$ (ed) Proceeding on 4th International UNESCO Conference on Geopark. April 12-15, 2010. Langkawi, Malaysia.

Herawan T, Na'iem M, Indrioko S, Indrianto A. 2014. Somatic embryogenesis of Sandalwood (Santalum album L.). Indo J Biotech, December 2014. Vol. 19, No. 2, pp.168-175.

Hmeljevski KV, Freitas L, Domingues R, Pereira AR, Cancio AS Andrade AC, Machado MA, Viccini LF, Forzza RC. 2014. Conservation assessment of an extremely restricted bromeliad highlights the need for population-based conservation on granitic inselbergs of the Brazilian Atlantic Forest. Flora 209: 250-259.

Indrioko S, Ratnaningrum YWN. 2015(a). Habitat loss caused clonality, genetic diversity reduction and reproductive failure in Santalum album, an endangered endemic species of Indonesia. Proc Env Sci V: 613-620.

Indrioko S, Ratnaningrum YWN. 2015(b). The effects of habitat degradation on gene dynamics and reproductive fitness in several populations of sandalwood in Nusa Tenggara Timur. Universitas Gadjah Mada. Yogyakarta. [Indonesian]

IUCN. 1994. IUCN Red List Categories and Criteria: Version 2.3. IUCN Species Survival Commission. International Union for Conservation of Nature and Natural Resources. Glad, Switzerland, and Cambridge, UK.

IUCN. 2009. IUCN Red List Categories and Criteria: Version 3.1. IUCN Species Survival Commission. International Union for Conservation of Nature and Natural Resources. Glad, Switzerland, and Cambridge, UK.

Kettle CJ, Hollingsworth PM, Jaffre T, Moran B, Ennos RA. 2007. Identifying the early genetic consequences of habitat degradation in a highly threatened tropical conifer, Araucaria nemorosa Laubenfels. Mol Ecol 16: 3581-3591.

Lhuillier E, Butaud JF, Bouvet JM. 2006. Extensive clonality and strong differentiation in the Insular Pacific tree Santalum insulare: implications for its conservation. Ann Bot 98: 1061-1072.

Lutz E, Schneller JJ, Holderegger R. 2000. Understanding population history for conservation purposes: population genetics of Saxifraga aizoides (Saxifragaceae) in the lowlands and lower mountains North of the Alps. Am J Bot 87 (4): 583-590.

Moreira PA, Brandao MM, Araujo NH, Oliveira DA, Fernandes GW. 2015. Genetic diversity and structure of the tree Enterolobium contortisiliquum (Fabaceae) associated with remnants of a seasonally dry tropical forest. Flora 210: 40-46.

Nei M. 1987. Molecular Evolutionary Genetics. Columbia University, New York, USA.

Pautasso M. 2009. Geographical genetics and the conservation of forest trees. Persp Plant Ecol, Evol \& Syst 11: 157-189.

Rao MN, Ganeshaiah KN, Shaanker RU. 2007. Assessing threats and mapping sandal resources to identify genetic 'hot-spot' for in-situ conservation in peninsular India. Conserv Genet 8: 925-935.

Ratnaningrum YWN, Indrioko S, Faridah E, Syahbudin A. 2016. Flowering and seed production of sandalwood (Santalum album Linn., Santalaceae) along environmental gradients in Gunung Sewu Geopark, Indonesia. Nusantara Bioscience Vol. 8 No. 2, pp 180-191.

Ratnaningrum YWN, Indrioko S, Faridah E, Syahbudin A. 2015. The effects of population size on genetic parameters and mating system of sandalwood in Gunung Sewu, Indonesia. Indonesian Journal of Biotechnology. Vol 20 No. 2.

Ratnaningrum YWN, Indrioko S. 2015. Response of flowering and seed production of sandalwood (Santalum album linn., Santalaceae) to climate changes. Proc Env Sci V: 665-675.

Ratnaningrum YWN, Indrioko S. 2014. Variation on genotypes and flowering characters affecting pollination mechanisms of sandalwood (Santalum album Linn., Santalaceae) planted on ex-situ gene conservation in Yogyakarta, Indonesia. Eur J For Res 6: 167-179.

Schmidt T, Arens P, Smulders MJM, Billeter R, Liira J, Augenstein I, Durka W. 2009. Effects of landscape structures on genetic diversity of Geum urbanum L. populations in agricultural landscapes. Flora 204: 549-559.

Simanjuntak T. 2002. Gunung Sewu in Prehistoric Times. Gadjah Mada Univ. Press. Yogyakarta, Indonesia.

Sindhu-Veerendra HCS, Anantha-Padmanabha HSA. 1996. The breeding system in Sandal (Santalum album L.). Silvae Genetica 45 (4): 188190.

Suma TB, Balasundaran M. 2003. Isozyme variation in five provenances of Santalum album in India. Aust J Bot 51(3): 243 - 249.

Tamla HT, Cornelius JP, Page T. 2012. Reproductive biology of three commercially valuable Santalum species: development of flowers and inflorescences, breeding systems, and interspecific crossability. Euphytica 184: 323-333.

Torres E, Iriondo JM, Perez C. 2003. Genetic structure of an endangered plant, Antirrhinum microphyllum (Scrophulariaceae): allozyme and RAPD analysis. Am J Bot 90(1): 85-92.

Warburton CL, James EA, Fripp YJ, Trueman SJ, Wallace HM. 2000. Clonality and sexual reproductive failure in remnant populations of Santalum lanceolatum (Santalaceae). Biol Conserv Volume 96 Issue 1 .

Young AD, Boshier D, Boyle T. 2000. Forest Conservation Genetics: Principles and Practices. CSIRO Publishing. Collingwood, Australia.

Zhang ZY, Chen YY, Li DZ. 2005. Detection of low genetic variation in a critically endangered Chinese pine, Pinus squamata, using RAPD and ISSR markers. Biochem Genet 43: 239-249. 